\title{
A Case Study Evaluating Economic Implications of Two Grazing Strategies for Cattle Ranches in Northwest Argentina
}

\author{
R. Emiliano Quiroga, Lisandro J. Blanco, and Carlos A. Ferrando
}

Authors are Scientific Researchers, Estación Experimental Agropecuaria Juan Carlos Vera (La Rioja), Instituto Nacional de Tecnología Agropecuaria (INTA), CC26, 5380 Chamical, La Rioja, Argentina.

\begin{abstract}
In the Argentinean Chaco Arido region, cattle production based on cow-calf operations is the principal source of agricultural income, and rangeland is the main forage source for cattle. Traditional grazing strategy (TGS, high stocking rate and continuous grazing) is considered the main cause of current rangeland degradation. Research shows that rangeland and cattle production improvements are possible when using a conservative grazing strategy (CGS, moderate stocking rate and rest rotation grazing). The aim of this research was to compare the effects of TGS and CGS applications on economic results for a cattle ranch in the region. To achieve this objective we used an approach that included estimations of forage and cattle production, and economic results. The study period was 1972/73-1983/84. Results showed that during the study period forage production and herd size were almost doubled with CGS, but maintained with TGS. The difference in net income between CGS and TGS (in Argentinean pesos, $\$$ ), increased linearly from negative $\left(-\$ 2.88 \cdot \mathrm{ha}^{-1}\right)$ to positive $\left(\$ 4.48 \cdot \mathrm{ha}^{-1}\right)$ in the first $4 \mathrm{yr}$, and then was maintained at positive values (averaging $\$ 4.48 \cdot \mathrm{ha}^{-1}$ ). Data suggest that CGS leads to higher productivity and better economic results than TGS in the medium and long terms.
\end{abstract}

\section{Resumen}

En la región del Chaco Árido Argentino, la ganadería de cría es la actividad agropecuaria más difundida. Esta actividad se basa principalmente en el forraje que proporciona el pastizal nativo. La estrategia de pastoreo tradicional (EPT, consistente de alta carga animal y pastoreo continuo), se considera la causa principal del estado de degradación actual del pastizal nativo. Varios estudios han mostrado que el mejoramiento de la productividad del pastizal y del ganado es posible cuando se utiliza una estrategia de pastoreo conservativa (EPC, consistente en carga animal moderada y un pastoreo que permita descanso del pastizal en época de crecimiento). El objetivo de esta investigación fue comparar el efecto de la EPT y la EPC sobre el aspecto económico de un rancho ganadero de la región del Chaco Árido. Para lograr dicho objetivo se hizo un análisis en distintas etapas, estimación de la producción forrajera, estimación de la producción ganadera, y estimación del resultado económico. El periodo de estudio fue desde 1972/73 hasta 1983/84. Los resultados mostraron que durante el periodo de estudio la producción de forraje y el tamaño del rodeo se duplicaron para la EPC, mientras que para EPT se mantuvieron. La diferencia en el resultado económico neto entre la EPC y la EPT (en pesos Argentinos, \$), se incrementó linealmente desde valores negativos $\left(-\$ 2.88 \cdot \mathrm{ha}^{-1}\right)$ a valores positivos $\left(\$ 4.48 \cdot \mathrm{ha}^{-1}\right)$ en los cuatro primeros años, para luego mantenerse en un valor promedio de $\$ 4.48 \cdot \mathrm{ha}^{-1}$. Los resultados sugieren que la EPC permite obtener una productividad más alta y mejores resultados económicos que la EPT a mediano y largo plazo.

Key Words: cattle production, economic analysis, forage production, grazing strategy, semiarid rangeland

\section{INTRODUCTION}

The Chaco Arido region of Argentina covers approximately 10 million ha in eastern La Rioja and San Juan, western Cordoba, northern San Luis, and southern Santiago del Estero and Catamarca provinces (Morello et al. 1985). In this region, cattle production based on cow-calf operations is the principal source of agricultural income (Ferrando and Namur 1984), and

Research was funded by the Instituto de Nacional de Tecnología Agropecuaria (INTA).

Correspondence: R. Emiliano Quiroga, Estación Experimental Agropecuaria Catamarca, Instituto Nacional de Tecnología Agropecuaria (INTA), Ruta Provincial No. 33 Km 4, CP 4705, Sumalao, Valle Viejo, Catamarca, Argentina. Email: equiroga@correo.inta.gov.ar

Current address: Raúl E. Quiroga, Estación Experimental Agropecuaria Catamarca, Instituto Nacional de Tecnología Agropecuaria (INTA), Ruta Provincial No. 33 Km 4, CP 4705, Sumalao, Valle Viejo, Catamarca, Argentina.

Manuscript received 17 March 2008; manuscript accepted 8 May 2009. native grass species constitute the main forage source for cattle (Ferrando et al. 2001; Blanco et al. 2008).

The most frequent grazing strategy applied in the region consists of high stocking rates $(\sim 75 \%$ utilization of the annual forage production) and continuous grazing. This traditional grazing strategy (TGS) is considered the main cause of current rangeland degradation of the region (Anderson et al. 1980; Biurrun 1988). Research conducted in the region (Anderson et al. 1980; Anderson 1983) has shown that improvements in rangeland condition and cattle production are possible when using a conservative grazing strategy (CGS) consisting of moderate stocking rates $(\sim 50 \%$ utilization of the annual forage production) and rest rotation grazing (each paddock rested one growing season every $3 \mathrm{yr}$, so deferred grazing is applied to one-third of the ranch paddocks each year).

Even though productive benefits of CGS were widely communicated (Anderson et al. 1980; Orionte et al. 2001), CGS was seldom adopted. We consider that one of the main 
causes for the lack of adoption is ranchers' belief that CGS produces an economic disadvantage compared to TGS, because CGS requires an initial dramatic herd size reduction. The lack of studies comparing the economic results of both grazing strategies in the region could be one of the principal reasons. The aim of this study was to compare the effect of TGS and CGS applications on the economic results of a cattle ranch in the region. A major problem for this type of analysis is that, in the region, there is a total lack of productivity data for ranches managed under TGS. So we conducted a set of estimations to achieve forage and cattle production, and subsequent economic results. The test hypothesis was that CGS produces higher productive and economic results than TGS. The prediction associated with this hypothesis was that in the medium to the long terms, forage production and economic results of a ranch that changes from TGS to CGS will be increased with respect to one that continues applying TGS.

\section{Study Region}

This study was conducted in the Chaco Arido region located in northwestern Argentina, between lat $28^{\circ} 15^{\prime} \mathrm{S}$ and $33^{\circ} 30^{\prime} \mathrm{S}$, and long $64^{\circ} 01^{\prime} \mathrm{W}$ and $67^{\circ} 31^{\prime} \mathrm{W}$. Climate within the region is subtropical semiarid, with hot summers and mild winters. January is the month with highest average temperature $\left(26^{\circ} \mathrm{C}\right)$, and July is the coldest $\left(11^{\circ} \mathrm{C}\right)$. The spring and summer are from September to March (Prohasca 1959). Mean annual precipitation decreases from $500 \mathrm{~mm}$ in the east to $300 \mathrm{~mm}$ in the west, with $80 \%$ falling between October and March (Morello et al. 1985; Cabido et al. 1993). Soils are Aridisols and Entisols, with local texture variations (Gomez et al. 1993). Physiognomy of the vegetation is xerophytic shrubland with isolated trees and patches of grass (Morello et al. 1985). Dominant shrub genera are Larrea, Mimozyganthus, Senna, and Capparis. Dominant tree genera include Aspidosperma and Prosopis. The herbaceous layer is dominated by perennial $\mathrm{C}_{4}$ grasses of the genera Trichloris, Chloris, Pappophorum, Aristida, and Setaria (Ragonese and Castiglioni 1970; Morello et al. 1985). Overgrazing principally affects the herbaceous layer decreasing desired species and productivity (Anderson 1983). Ten thousand ranches raise cattle, with $60 \%$ of them on fenced properties and the remaining $40 \%$ on communal grazing lands (Diez et al. 1991). Annual cattle productivity indices for the region are low (calf crop $<50 \%$, beef productivity $=5 \mathrm{~kg} \cdot \mathrm{ha}^{-1}$ ). These low productivity indices are attributed to deteriorated rangeland conditions and to inadequate herd and grazing management practices (Diez et al. 1991; Orionte et al. 2001).

\section{MATERIALS AND METHODS}

Estimations of the two grazing strategy effects were carried out considering the "Balde El Tala" ranch as a model for our study. This is a 7200-ha ranch divided into 12 paddocks, located (lat $31^{\circ} 44^{\prime} \mathrm{S}$, long $66^{\circ} 02^{\prime} \mathrm{W}$ ) in the southern portion of the Chaco Arido region in La Rioja Province. This ranch was under TGS management before 1972 and under CGS management from 1972/73 to 1983/84 (Anderson et al. 1980; Orionte et al. 2001); hence we considered from $1972 / 73$ to $1983 / 84$ as the study period. For this period, we evaluated the effects of the real management strategy applied at "Balde El Tala" ranch (CGS), and of a hypothetical continuity in the application of TGS, on forage production, cattle production, and economic results of the model ranch. In Table 1 we summarize the main steps, estimation methods, and assumptions followed to achieve this objective; they also are explained in following sections.

\section{Forage Production Estimate}

We considered only perennial grasses to estimate forage production in both grazing strategies, because perennial grasses are the main source of forage for cattle in the region (Anderson et al. 1977). To estimate forage production of each grazing strategy, we used different approaches.

For CGS, we used perennial grass standing crop and cover datasets annually obtained at the end of the growing season from 1973 to 1984 at "Balde El Tala" ranch (Anderson et al. 1980; E. L. Orionte, personal communication, March 2004). Perennial grass standing crop was annually estimated by clipping (20 frames of $0.25 \mathrm{~m}^{2}$ ) in one deferred paddock. We considered annual perennial grass standing crop as annual forage production. Perennial grass cover was annually estimated by the Canopy-Coverage Method (Daubenmire 1959), in 32 permanent transects distributed representatively on the ranch. Ten $0.25-\mathrm{m}^{2}$ frames were measured in each transect. By using annual datasets of both variables measured in the same paddock, we developed the following regression equation between forage production (dependent variable) and perennial grass cover (independent variable):

$$
\mathbf{F P}_{\mathbf{C G S}}=-125.26+16.92 \cdot \mathbf{C} \quad\left(R^{2}=0.64 ; P=0.0018\right), \quad[
$$

where $\mathbf{F P}_{\mathbf{C G S}}$ is annual forage production $\left(\mathrm{kg} \cdot \mathrm{ha}^{-1}\right)$ and $\mathbf{C}$ is the mean annual perennial grass cover $(\%)$.

Then we calculated the mean annual perennial grass cover of the total ranch, averaging only data of perennial grass cover obtained from transects located on nongrazed areas. Mean annual forage production of the total ranch was estimated from these measured cover values by replacing $C$ in equation [1] by the mean annual perennial grass cover of the total ranch.

For TGS, we estimated forage production from datasets of "normalized differential vegetation index" (NDVI) and of precipitation obtained from 1981 to 2000 in two selected rangelands ("Cuatro Esquinas" zone: lat $31^{\circ} 48^{\prime} \mathrm{S}$, long $65^{\circ} 52^{\prime} \mathrm{W}$; "San Solano" zone: lat $31^{\circ} 28^{\prime} \mathrm{S}$, long $\left.65^{\circ} 55^{\prime} \mathrm{W}\right)$. These zones, each 6400 ha, are located near "Balde El Tala" ranch and were managed under TGS for the last $50 \mathrm{yr}$. Soils, vegetation, and potential productivity of these zones were similar to those of "Balde El Tala" ranch (Cabido et al. 1993; Gomez et al. 1993). No NDVI data were available from 1972 to 1980 , so we used NDVI data of years (from 1981 to 2000) not included in the study period. We used a NDVI dataset of 10-d composites (Holben 1986; Holm et al. 2003) of National Oceanic and Atmospheric Administration (NOAA) Advanced Very High Resolution Radiometer Global Area Coverage (pixel size $=8 \times 8 \mathrm{~km}$ ) images for each growing season. We calculated the NDVI integral (I-NDVI) of each growing season (from $1981 / 82$ to $1999 / 2000$ ) by the mobile baseline method (Holm et al. 2003). According to Sellers et al. (1992), I-NDVI is a good estimator of the amount of radiation intercepted by the green canopy throughout the growing season; hence it is also a 
Table 1. Main steps, estimation methods, and assumptions in the analysis. ${ }^{1}$

\begin{tabular}{|c|c|c|c|c|}
\hline \multirow[b]{2}{*}{ Analysis steps } & \multicolumn{2}{|c|}{ Estimation methods } & \multicolumn{2}{|c|}{ Assumptions } \\
\hline & CGS & TGS & CGS & TGS \\
\hline \multirow[t]{2}{*}{$\begin{array}{l}\text { Forage production } \\
\text { estimate }\end{array}$} & $\begin{array}{l}\text { a) Relationship between field data (1972/73- } \\
\text { 1983/84) of FP and annual perennial grass } \\
\text { cover (equation [1]). b) Estimate of total } \\
\text { ranch FP by replacing total ranch mean }\end{array}$ & $\begin{array}{l}\text { a) ANPP estimate by replacing I-NDVI data (1981/ } \\
\text { 82-1999/2000) of two areas near "BET" ranch, } \\
\text { using equation [2] (Holm et al. 2003). b) FP } \\
\text { estimate of the two areas (1981/82-1999/00) }\end{array}$ & $\begin{array}{l}\text { - Model ranch = "BET" ranch. } \\
\text { - Study period }=\text { from } 1972 / 73 \text { to } 1983 / 6 \\
\text { - } F P=\text { annual perennial grass production }\end{array}$ & (Ferrando et al. 2001; Blanco et al. 2008). \\
\hline & annual perennial grass cover in equation [1]. & $\begin{array}{l}\text { by multiplying ANPP by a correction factor } \\
\text { (0.28). Correction factor is perennial grass } \\
\text { cover proportion of total vegetation cover } \\
\text { (Cabido et al. 1993). C) Relationship between } \\
\text { FP and precipitation annual values of the } \\
\text { two areas (1981/82-1999/2000, equation } \\
\text { [3]). d) Estimate of FP (1972/73-1983/84) by } \\
\text { replacing annual precipitation values of "BET" }\end{array}$ & $\begin{array}{l}\text { - Annual perennial grass production }= \\
\text { annual perennial grass standing crop } \\
\text { biomass. }\end{array}$ & $\begin{array}{l}\text { - The two TGS selected areas have similar } \\
\text { soils, vegetation, and potential } \\
\text { productivity as "BET" ranch (Gomez et al. } \\
\text { 1993). } \\
\text { - Relationship between annual perennial } \\
\text { grass production and ANPP is similar to } \\
\text { the relationship between perennial grass } \\
\text { cover and total vegetation cover. }\end{array}$ \\
\hline
\end{tabular}

Cattle production $\quad$ a) Herd size adjustments every 3 yr considering FP of three previous years and the utilization factor estimate for each grazing strategy (CGS $=50 \%$ and TGS $=75 \%$ ). b) Annual cattle production estimate considering body weight of cull animals (cows, bulls, and heifers) and of nonreplacement animals (calves).

- Herd composition according to Anderson et al. (1980).

- AU = daily forage intake annual average of $9 \mathrm{~kg}$ of dry matter (Del Aguila et al. 1969).

- Animal category equivalences in respect to AU according to Oesterheld et al. (1998).

- Herd composition according to Anderson et al. (1980).

- Forage utilization factor $=50 \%$ for CGS (Anderson et al. 1980) and $75 \%$ for TGS (calculated from Diez et al. 1987).

- Animal body weight and reproductive performance for CGS according to Anderson (1980) and for TGS according to Holechek (1994) and Holechek et al. (1999).

- Yearling and mature cattle mortality = not considered.

Net income estimate a) Annual income estimate considering cattle sales and purchases, and forage marketing (Kipple and Bement 1961). b) Annual cost estimate considering expenses, interests, amortizations, and taxes (Penna et al. 1980). c) Annual net income estimate considering the difference between annual

- Ranch improvements according to
similar in both grazing strategies.

income and annual cost (Penna et al. 1980).

- Prices corresponding to August 2007 (according to the Instituto Nacional de Estadística y Censo, INDEC, http://www.indec.mecom.ar).

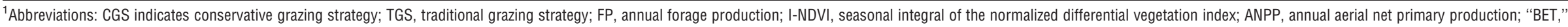
"Balde El Tala"; and AU, animal unit. 
good estimator of seasonal aerial net primary production (ANPP). I-NDVI has been used previously in the Chaco Arido region (Blanco et al. 2008) to estimate the grazing effect on ANPP, but no equation relating I-NDVI and ANPP has been developed for the Chaco Arido region. So we estimated ANPP of the two selected zones using the following equation developed by Holm et al. (2003) in a similar semiarid region of Australia:

$$
\mathbf{A N P P}=10 \cdot(-25.67+3.33 \cdot \mathbf{I}-\mathbf{N D V I}),
$$

where ANPP is the annual aerial net primary production $\left(\mathrm{kg} \cdot \mathrm{ha}^{-1}\right)$ and I-NDVI is the annual integral of the normalized vegetation index.

Annual forage production of each zone for the 1981/821999/2000 period was calculated multiplying ANPP values by a correction factor (correction factor $=0.28$ ). The correction factor represents the relationship between perennial grass cover and total vegetation cover, as described by Cabido et al. (1993) for both zones.

Using annual forage production $\left(\mathrm{kg} \cdot \mathrm{ha}^{-1}\right)$ as dependent variable $(\mathbf{y})$ and annual precipitation $(\mathrm{mm})$ as independent variable $(\mathbf{x})$, we developed the following equation for the period 1981/82-1999/2000 at the TGS-managed zones:

$$
\mathbf{y}=278+0.44 \cdot \mathbf{x} \quad\left(P=0.0080 ; R^{2}=0.40\right)
$$

Thus, to estimate annual forage production for "Balde El Tala" ranch under TGS from 1972/73 to 1983/84, we replaced the independent variable of this equation with the annual precipitation values of the mentioned period in "Balde El Tala" ranch.

We used different approaches to get forage production for each grazing strategy because no field data were available for TGS managed rangelands, and it was not possible to get any NOAA pixel completely covered by CGS-managed rangeland ("Balde El Tala" ranch). Even though methods to estimate forage production for CGS and TGS were different, two facts encouraged us to continue with the analysis: 1) estimated annual forage productions for both grazing strategies at the first year of study period $\left(1972 / 73, \sim 430 \mathrm{~kg} \cdot \mathrm{ha}^{-1}\right)$ were similar (see Results), and 2) annual forage productions, estimated by NDVI along the study period for TGS, were consistent with field data of forage production on poor condition rangelands of Chaco Arido region (Blanco et al. 2004, 2005).

\section{Cattle Production Estimate}

To facilitate economic analysis in both grazing strategies, we considered two relatively common practices applied in the region to adjust forage demands of the herd to forage availability in the ranch (Penna et al. 1980). The first practice consists of medium-term interval $(2-5 \mathrm{yr})$ adjustments by animal sales or purchases, and the second practice consists of annual adjustments (whatever necessary) by forage sales or purchases.

To estimate cattle production in both grazing systems, we simulated changes in the herd size every $3 \mathrm{yr}$ by adjusting the stocking rate to the average annual forage production of the three previous years. For the first $3 \mathrm{yr}$ only we estimated the stocking rate according to the annual forage production of the first year. Stocking rate (animal units per hectare, $\mathrm{AU} \cdot \mathrm{ha}^{-1}$ ) for CGS was calculated considering $50 \%$ of utilization of the annual forage production (stocking rate applied at "Balde El Tala" ranch since 1972) according to Anderson et al. (1980). Stocking rate for TGS was calculated considering $75 \%$ of utilization of the annual forage production. Utilization percentage of TGS was estimated considering 1) cattle stock of San Martin County (Diez et al. 1987), where "Balde El Tala" ranch is located, 2) the county surface dedicated to cattle activity (Diez et al. 1987), and 3) the estimated annual forage production of TGS. For the purpose of this study, we considered that AU represents an annual average daily forage intake of $9 \mathrm{~kg}$ of dry matter, hence $3285 \mathrm{~kg}$ of forage per year (Del Aguila et al. 1969). Animal category equivalences with respect to animal units were estimated according to Oesterheld et al. (1998).

The herd composition of both grazing strategies was calculated according to Anderson et al. (1980). Annual cattle production per hectare $\left(\mathrm{kg} \cdot \mathrm{ha}^{-1}\right)$ was calculated considering cull (cows, bulls, and heifers) and nonreplacement animals (calves). We considered the following assumptions to calculate cattle production: 1) $20 \%$ of herd (cows and bulls) replacement per year in both grazing strategies; 2) we did not consider yearling and mature cattle mortality in our analysis because a) this parameter was negligible $(0 \%)$ for CGS (Anderson et al. 1980), and b) although we felt mortality for TGS could be higher than for CGS, we did not have reliable data for former strategy; 3) $80 \%$ of weaning for CGS (Anderson et al. 1980) and $65 \%$ for TGS (estimated by a linear regression equation considering data from Holechek et al. 1999); 4) animal body weight of each herd class according to registers of "Balde El Tala" ranch for CGS (Anderson et al. 1980), and for TGS calculated as 3\% less than for CGS, because of the increase in stocking rate (Holechek 1994). Even though reductions in weaning percentage and animal body weight for TGS were estimated from the bibliography, we know that they were conservative relative to observations in the region (Orionte et al. 2001).

\section{Economic Analysis}

Our economic analysis was performed following methodology used by Penna et al. (1980) and considering money values corresponding to August 2007 (according to the Instituto Nacional de Estadística y Censo, INDEC, http://www.indec. mecom.ar). Economic variables were expressed in Argentinean pesos (\$). Equivalency between Argentinean pesos and US dollars (US\$) was $\$ 3.1=$ US\$1. Net income for each year and for each grazing strategy was calculated as the difference between income and costs. For both grazing strategies we considered existing improvements on "Balde El Tala" ranch in 1972, because this ranch changed from TGS to CGS in 1972 without any need of additional improvements (Anderson et al. 1980).

Income for both grazing strategies was calculated considering cattle marketing, inventory difference, and the forage marketing (sales and purchases were added to or reduced from the income, respectively) method of regulation of the animal consumption in the short term. So, as we calculated, forage marketing impacted only income and not costs.

For each grazing strategy, changes in stocking rate every 3 yr were made by animal sales and purchases. Prices for each 


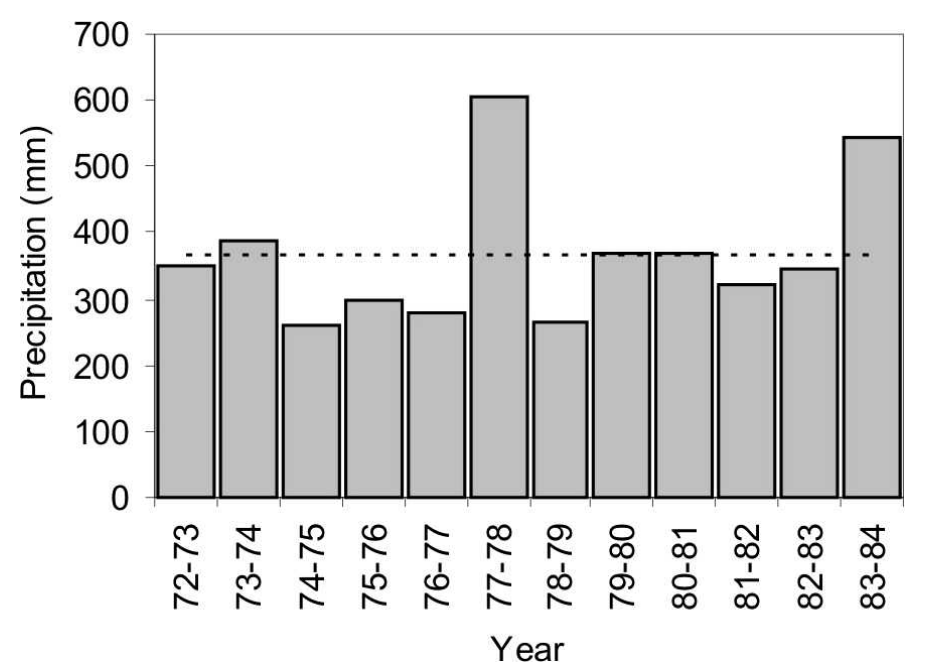

Figure 1. Annual precipitation (bars) recorded from July to June, for the period 1972/73-1983/84 at "Balde El Tala" ranch, located in Chaco Arido region (Argentina). Dashed line represents the mean annual precipitation $(365 \mathrm{~mm}$ ) for the period.

animal class were obtained from registers of the Sociedad Rural del Sur Riojano, an important cattle auction center of the region. Mean price per AU, for each grazing strategy, was estimated by dividing the total value of the herd, considering all animal classes, by the total number of AU. Inventory difference was determined every $3 \mathrm{yr}$, considering increases or decreases in the quantity of $\mathrm{AU}$ of the ranch and the mean $\mathrm{AU}$ price.

Economic impact of the lack or excess of forage that occurred in both grazing strategies was estimated using the market forage method, which was a method used previously to valuate forage excess or lack in ranches (Kipple and Bement 1961). However, in our study this method was also appropriate to introduce the annual variation in ranch net income caused by annual precipitation. This was central because of the temporal stability that we confer to animal indexes in the analysis. Annual forage sales or purchases were calculated as the difference between the consumable forage $(75 \%$ and $50 \%$ of the total forage production for TGS and CGS, respectively) and the herd requirements for each grazing strategy. In our study, forage price was estimated at $\$ 16 \cdot \mathrm{AU}^{-1} \cdot \mathrm{month}^{-1}$ and animal hauling (in a rented truck) price was estimated as $\$ 0.032 \cdot \mathrm{AU}^{-1} \cdot \mathrm{km}^{-1}$. Animal hauling price was considered only when there was a lack of forage and animals were hauled to another ranch. No need of additional improvements was necessary in both grazing strategies to marketing forage.

Costs for both grazing strategies included expenses, interests, amortizations, and taxes (Penna et al. 1980). Expenses for both grazing strategies included operational expenses and structural expenses. Operational expenses included one permanent worker, technical advice (12 visits per year), transportation needs, herd veterinary treatments, pregnancy detection through rectal palpation of cows, clinic and genital control of bulls and heifers, and mineral supplementation. Structural expenses included vehicle and improvement maintenance $5 \%$ and $2.5 \%$ of their price, respectively). Interest was calculated as $7 \%$ of the expenses. Amortizations included improvements $(75 \mathrm{~km}$ of fences, 3 windmills, 3 pumps, 3 tanks, 3 water troughs, and 1 chute),

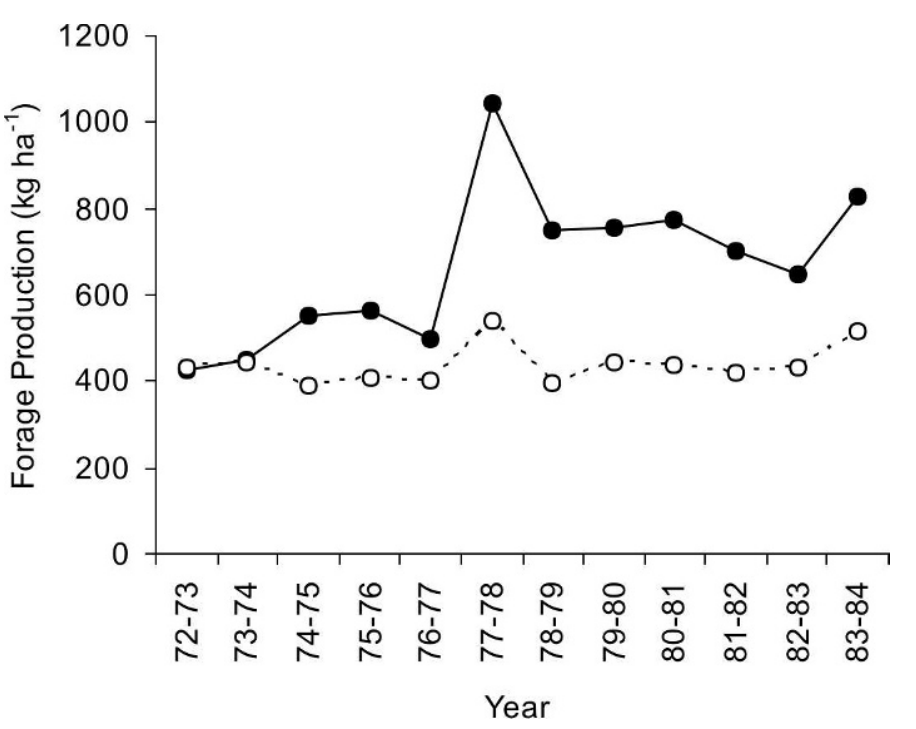

Figure 2. Annual forage production (from July to June) estimations for the period 1972/73-1983/84 on a cattle ranch of the Chaco Arido (Argentina) managed under conservative grazing strategy (continuous line and black circles) or traditional grazing strategy (dashed line and white circles).

draft animals (4 horses), and vehicles ( 1 truck). Taxes included $10.5 \%$ of animal sales, services payment, and land tax.

To compare economic results between both grazing strategies, we used regression analysis considering time as an independent variable and the difference between net income of CGS and net income of TGS (Dif_NI) for each year as the dependent variable. A sensitivity analysis of the net income for each of the grazing strategies was performed considering cattle prices 20\% lower than those used in the present study (August 2007). Sensitivity analysis was carried out for the total study period (1972/73-1983/84) for TGS, and the last 5 yr (1978/791983/84) for CGS when forage production was stable in the last strategy. Analysis of variance was performed to determine the proportion of variance in the net income (dependent variable) as explained by the following independent variables: annual precipitation (random effect), cattle price, and grazing strategy (fixed effects). The proportion of variance explained by each independent variable was obtained by dividing the sum of squares of each independent variable by the total sum of squares (Welden and Slauson 1986). Statistical analysis was performed using SAS statistical software (SAS Institute 1996).

\section{RESULTS}

Annual precipitation (July to June) for the 1972/73-1983/84 period at "Balde El Tala" ranch showed no trend through time $(P=0.4912)$. Mean annual precipitation and its standard deviation for this period were $365 \mathrm{~mm}$ and $107 \mathrm{~mm}$, respectively. Two years (1977/78 and 1983/84) were relatively humid, 6 yr (1972/73, 1973/74, 1979/80, 1980/81, 1981/82, and 1982/83) were relatively normal, and 4 yr (1974/75, 1975/ 76, 1976/77, and 1978/79) were relatively dry (Fig. 1).

Annual forage production, during the study period, showed a positive trend for CGS $(P=0.0345)$, but did not show any trend for TGS $(P=0.3660)$. While mean annual forage 


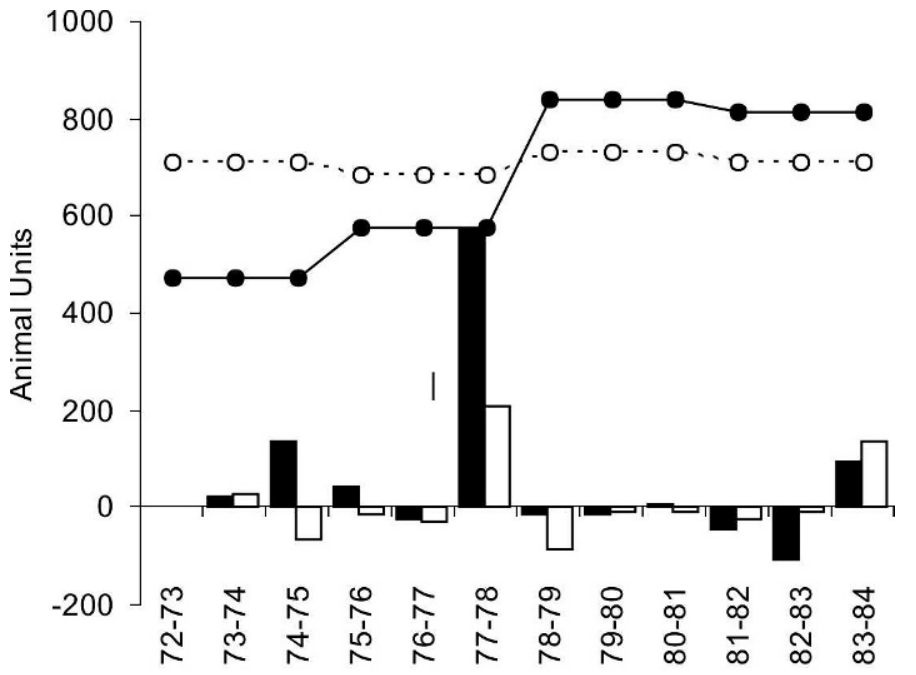

Year

Figure 3. Herd size (in animal units) on a cattle ranch (7200 ha) in the Chaco Arido region (Argentina), managed under conservative grazing strategy (CGS, continuous line and black circles) or traditional grazing strategy (TGS, dashed line and white circles) during the period 1972/731983/84. Variation in forage excesses and deficits are also represented (black bars for CGS and white bars for TGS), expressed in animal units (AU) considering that $1 \mathrm{AU}$ intakes $3285 \mathrm{~kg}$ of forage per year.

production at CGS changed from $500 \mathrm{~kg} \cdot \mathrm{ha}^{-1}$ in the first half of the study period (from $1972 / 73$ to $1976 / 77$ ) to $800 \mathrm{~kg} \cdot \mathrm{ha}^{-1}$ in the second half of the study period (from 1978/79 to 1983/ 84 ), it stayed near $440 \mathrm{~kg} \cdot \mathrm{ha}^{-1}$ for the total study period at TGS (Fig. 2). Maximum annual forage production for each grazing strategy was $1047 \mathrm{~kg} \cdot \mathrm{ha}^{-1}$ for CGS and $543 \mathrm{~kg} \cdot \mathrm{ha}^{-1}$ for TGS. Maximum annual forage production for both grazing strategies was coincident with the year of the highest precipitation (604 mm, 1977/78).

Annual stocking rate for TGS stayed relatively constant during the study period, presenting a mean value of 0.099 $\mathrm{AU} \cdot \mathrm{ha}^{-1}\left(=10.1 \mathrm{ha} \cdot \mathrm{AU}^{-1}\right)$. In contrast, annual stocking rate for CGS increased from $0.066 \mathrm{AU} \cdot \mathrm{ha}^{-1}\left(=15.2 \mathrm{ha} \cdot \mathrm{AU}^{-1}\right)$ for the first $3 \mathrm{yr}$ to $0.113 \mathrm{AU} \cdot \mathrm{ha}^{-1}\left(=8.8 \mathrm{ha} \cdot \mathrm{AU}^{-1}\right)$ for the last $3 \mathrm{yr}$ of the study period (Fig. 3). Forage deficits and excesses for each year and grazing strategy, expressed in animal units per year (1 AU intake $=3285 \mathrm{~kg}$ of forage per year), can be observed in Figure 3. Total amounts of forage deficit for the study period (1972/73-1983/84) were -206 AU and -239 AU for CGS and for TGS, respectively. Total amounts of forage excess for the study period were $876 \mathrm{AU}$ and $371 \mathrm{AU}$ for CGS and for TGS, respectively.

Annual beef production at TGS showed little change across time, and its mean value was $8.98 \mathrm{~kg} \cdot \mathrm{ha}^{-1}$. For this strategy, the calf crop represented $42 \%$ of total beef production. In contrast, annual beef production at CGS increased from $7.13 \mathrm{~kg} \cdot \mathrm{ha}^{-1}$ for the first $3 \mathrm{yr}$ to $12.25 \mathrm{~kg} \cdot \mathrm{ha}^{-1}$ for the last $3 \mathrm{yr}$ of the study period. For this strategy, the calf crop represented $50 \%$ of total beef production.

Income from market cattle and forage, and inventory difference, was influenced by annual forage productivity. In the short term (1972/73 and 1973/74), income at TGS was greater than at CGS, but in the medium (from 1974/75 to 1978/

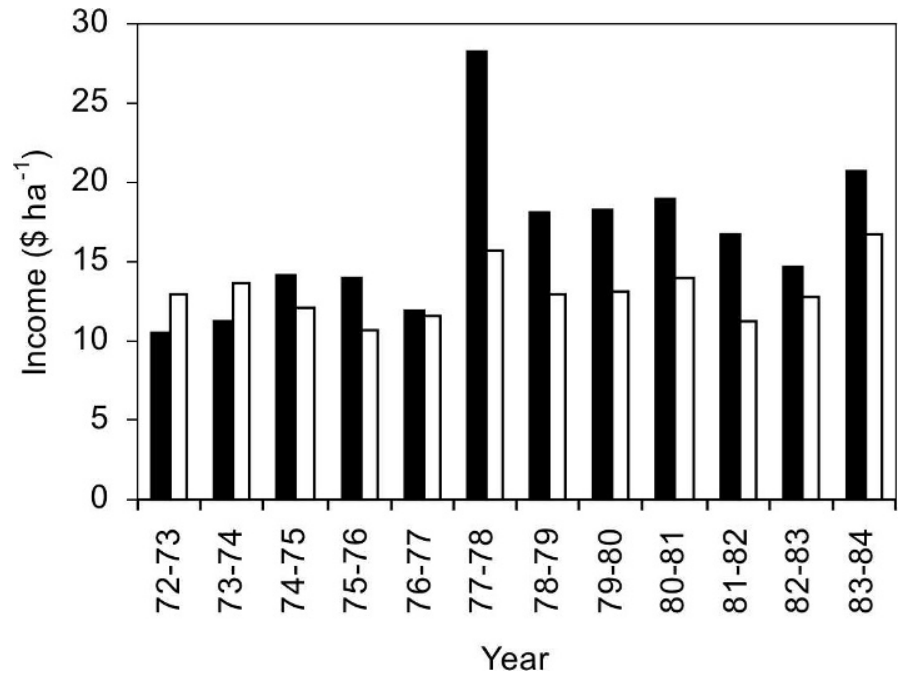

Figure 4. Income on a cattle ranch of the Chaco Arido region (Argentina) managed under conservative grazing strategy (black bars) or traditional grazing strategy (white bars) during the period 1972/731983/84. Income was calculated considering cattle and forage marketing and inventory difference. Values updated to August 2007.

79) and the long terms (from 1979/80 to 1983/84), income at CGS was greater than at TGS (Fig. 4). Annual average net contribution of market forage for CGS was $\$ 1.41 \cdot \mathrm{ha}^{-1}$, while for TGS, it was $\$ 0.19 \cdot \mathrm{ha}^{-1}$.

Average annual costs were similar between CGS and TGS $\left(\$ 11.02 \cdot \mathrm{ha}^{-1}\right.$ and $\$ 10.93 \cdot \mathrm{ha}^{-1}$, respectively; Table 2$)$. Operational expenses for TGS were slightly greater than for CGS (\$4.05 $\cdot \mathrm{ha}^{-1}$ vs. $\$ 3.95 \cdot \mathrm{ha}^{-1}$, respectively), but CGS showed higher taxes than TGS $\left(\$ 2.06 \cdot \mathrm{ha}^{-1}\right.$ vs. $\$ 1.87 \cdot \mathrm{ha}^{-1}$, respectively). Operational expenses for TGS were slightly higher than for CGS because average herd size through the study period for the former was larger than for the latter. Expenses for veterinary treatment, pregnancy detection by rectal palpation of cows, clinic and genital control of bulls and heifers, and mineral supplementation for TGS were higher than for CGS. Taxes for CGS were higher than for TGS, because the former showed higher average beef sales for the study period.

Net income of cattle activity followed similar tendencies and fluctuations as forage productivity in both grazing strategies (Figs. 2 and 5). Average annual net income for TGS was $\$ 2.14 \cdot \mathrm{ha}^{-1}$; annual net income for this strategy stayed relatively constant throughout the study period although a negative value occurred in 1975/76. Average annual net income for CGS was $\$ 5.46 \cdot \mathrm{ha}^{-1}$ although a negative value occurred in 1972/73. Annual net income for CGS changed from $\$ 2.14 \cdot \mathrm{ha}^{-1}$ in the first half of the study period (from 1972/73 to 1976/77) to $\$ 6.14 \cdot \mathrm{ha}^{-1}$ in the second half of the study period $(1978 / 79$ to 1983/84). Only in the first $2 \mathrm{yr}(1972 / 73$ and 1973/74) of the study period was TGS net income higher than CGS net income, because of the fact that forage productivity values for the two grazing strategies were similar, but the stocking rate and cattle production for TGS were higher than that for CGS. Beginning in the third year (1974/75) and throughout the rest of the study period, net income for CGS was higher than that for TGS. These last results were associated with higher forage productivity, which determined higher forage sales and cattle production for CGS than for TGS. The economic contribution of forage 
Table 2. Estimated costs for a cattle ranch of the Chaco Arido region (Argentina) managed under conservative grazing strategy (CGS) or traditional grazing strategy (TGS). Mean annual values $\left(\$ \cdot \mathrm{ha}^{-1}\right)$ for the period 1972/73-1983/84 (updated to August 2007) are presented.

\begin{tabular}{lcc}
\hline & CGS & TGS \\
\hline Amortizations & & \\
Fences $(75 \mathrm{~km})$ & 1.67 & 1.67 \\
Windmills (3) & 0.08 & 0.08 \\
Pumps (3) & 0.02 & 0.02 \\
Tanks (3) & 0.04 & 0.04 \\
Water troughs (3) & 0.02 & 0.02 \\
Chute (1) & 0.04 & 0.04 \\
Draft animals (4) & 0.04 & 0.04 \\
Vehicle (1) & 1.00 & 1.00 \\
Operational expenses & & \\
Permanent worker & 0.88 & 0.88 \\
Technical advice & 0.24 & 0.24 \\
Transportation needs & 0.39 & 0.39 \\
Herd veterinary treatments & 0.47 & 0.48 \\
Pregnancy detection & 0.10 & 0.11 \\
Control of bulls and heifers & 0.35 & 0.37 \\
Mineral supplementation & 1.52 & 1.58 \\
Structural expenses & & \\
Vehicle maintenance & 0.50 & 0.50 \\
Improvement maintenance & 1.20 & 1.20 \\
Interest & 0.40 & 0.40 \\
Taxes & 2.06 & 1.87 \\
Total costs & 11.02 & 10.93 \\
\hline
\end{tabular}

marketing was 7 -fold higher for CGS than for TGS, while the amount of available forage for sale was 5 -fold higher for CGS than for TGS. This difference (7-fold vs. 5-fold) was due to the fact that under TGS, a higher number of animals were transported to another ranch for grazing, which resulted in greater costs for animal transport.

Difference between net income of CGS and net income of TGS (Dif_NI) throughout the study period showed two defined subperiods. Therefore, we used a simple two straight-line, onebreakpoint regression model (Robbins et al. 2006) to analyze the Dif_NI trend through time (Fig. 6). The adjusted simple two straight-line, one-breakpoint regression model showed a positive trend (slope $=\$ 2.83 \cdot \mathrm{ha}^{-1} \cdot$ year $^{-1} ; P=0.0354$ ) from $1972 / 73$ to $1975 / 76$, and a plateau of $\$ 4.48 \cdot \mathrm{ha}^{-1}$ (inferior and superior $95 \%$ confidence limits were $\$ 1.95 \cdot \mathrm{ha}^{-1}$ and $\$ 7.03 \cdot \mathrm{ha}^{-1}$, respectively) from $1975 / 76$ to $1983 / 84$. Negative Dif_NI values were found only for the first 2 yr (1972/73 and 1973/74).

Sensitivity analyses showed that a $20 \%$ reduction of cattle price determined an important reduction in the net income of both grazing strategies. While CGS annual net income (for the period $1978 / 79-1983 / 84$ ) fell from $\$ 6.14 \cdot \mathrm{ha}^{-1}$ to $\$ 2.83 \cdot \mathrm{ha}^{-1}$, TGS annual net income (for the total study period, 1972/731983/84) fell from $\$ 2.14 \cdot \mathrm{ha}^{-1}$ to $-\$ 0.26 \cdot \mathrm{ha}^{-1}$. Considering $\$ 19200$ as minimum annual net income required by a family (according to Genovés et al. 2003; and updated to August 2007 prices according to INDEC, http://www.indec.mecon.ar) and a 7200-ha ranch, the minimum annual net income required by a family is $\$ 2.67 \cdot \mathrm{ha}^{-1}$. Although CGS annual net income was

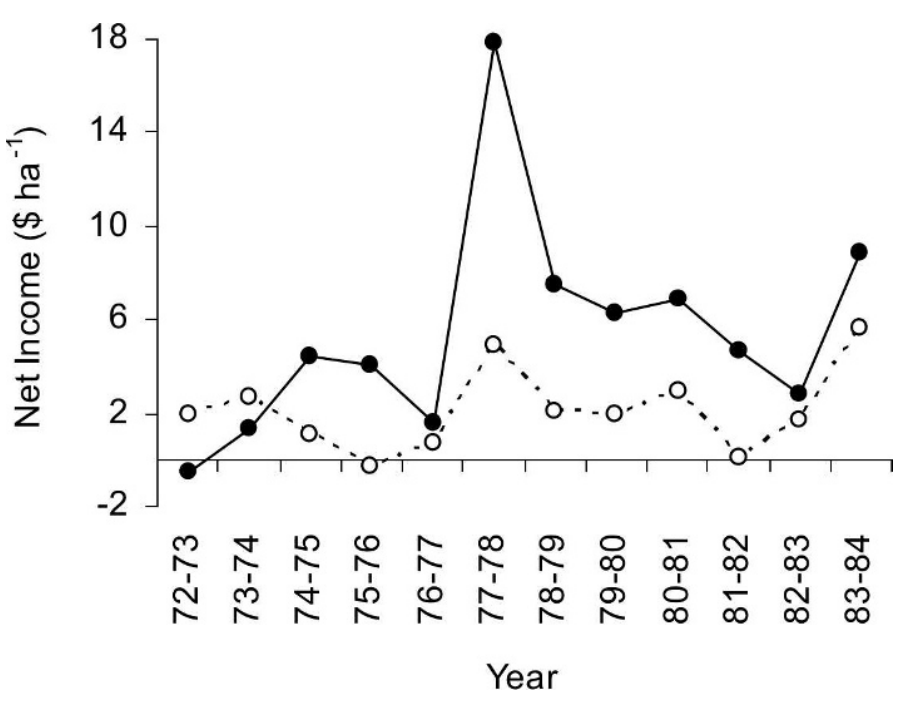

Figure 5. Annual net income on a cattle ranch of the Chaco Arido region (Argentina) managed under conservative grazing strategy (continuous line and black circles) or traditional grazing strategy (dashed line and white circles) during the period 1972/73-1983/84. Values updated to August 2007.

always higher than this value (even considering a $20 \%$ reduction of cattle prices), TGS annual net income was always lower.

Results of analysis of variance showed that grazing strategy, reduction in cattle prices, and annual precipitation explained $16 \%, 13 \%$, and $49 \%$ of total variability in net income, respectively. The three variables were significant $(P<0.01)$.

\section{DISCUSSION}

\section{Grazing Strategy and Forage Production}

Studies of grazing effects on vegetation conducted in different regions of the world have shown contradictory results

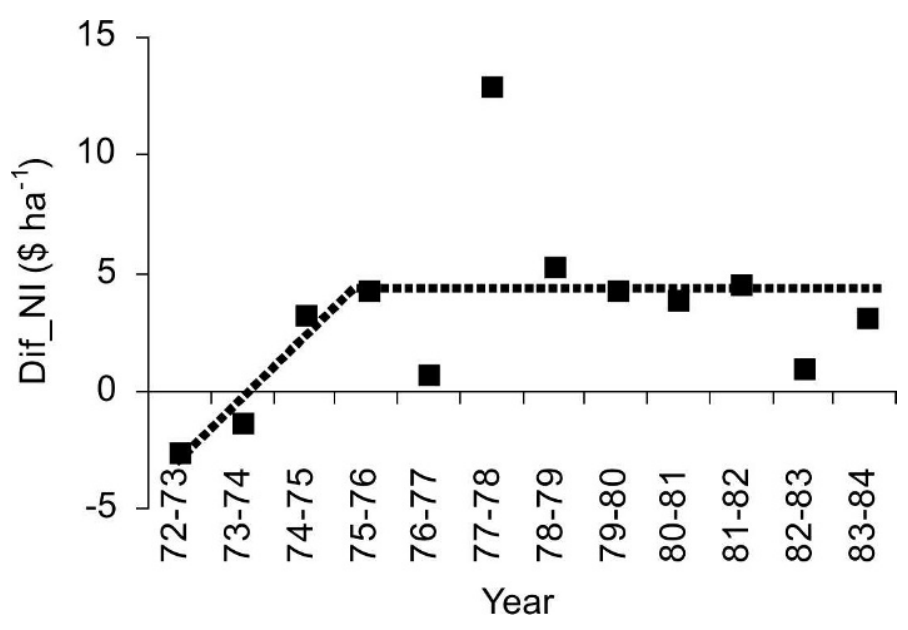

Figure 6. Simple two straight-line, one-breakpoint regression model adjusted between Dif_NI (difference between the net income of conservative grazing strategy and traditional grazing strategy) and time (years 1972/73-1983/84). A positive trend (slope $=\$ 2.83 \cdot \mathrm{ha}^{-1} \cdot \mathrm{yr}^{-1}$; $P=0.0354$ ) was observed from $1972 / 73$ to $1975 / 76$. There was a plateau (at $\$ 4.48 \cdot \mathrm{ha}^{-1}$ ) from $1975 / 76$ to $1983 / 84$. Negative Dif_NI values were found only during the first $2 \mathrm{yr}$ (1972/73 and 1973/74). Values updated to August 2007. 
(Milchunas and Lauenroth 1993). According to the successional model (Clements 1916; Dyksterhuis 1949), grazing pressure management is an important tool to reverse vegetation degradation. However, Westoby et al. (1989) reviewed studies from different rangelands of the world and pointed out that grazing management, by itself, has often been found insufficient to reverse vegetation degradation, particularly in arid and semiarid regions. In the Argentinean Chaco Arido region, it has been claimed that the traditional grazing strategy (TGS, high stocking rate and continuous grazing) is one of the main causes for native forage resource degradation (Anderson et al. 1980; Biurrun 1988). Although our results showed no decrease in forage productivity throughout the study period with TGS, forage productivity for this strategy remained at low levels. On the other hand, forage productivity for the conservative grazing strategy (CGS, moderate stocking rate and rest rotation grazing) showed a positive trend throughout the study period. These results suggest the following: 1) overgrazing would be a central factor related to present rangeland degradation in the Argentinean Chaco Arido region, which is consistent with assessments by Anderson et al. (1980) and Biurrun (1988); and 2) grazing management could be an important tool to recover forage productivity of degraded rangelands in the Argentinean Chaco Arido region, which would be consistent with the successional model (Clements 1916; Dyksterhuis 1949).

It is assumed that heavy grazing is detrimental for arid and semiarid range forage productivity because it removes leaf area necessary to absorb sufficient radiation for plant functioning or even survival (Briske et al. 2008). In contrast, there has been insufficient evidence supporting benefits of rotational grazing relative to continuous grazing in terms of forage or cattle production when they are at the same stocking rate (Holechek et al. 1987; Briske et al. 2008). However, Müller et al. (2007) showed, in a simulation study, that rest periods could play an indispensable role on the sustainability and productivity of arid and semiarid grazing rangelands where vegetation has low regeneration potential. In our study, the aim was to evaluate the coupled effects of resting and stocking rate (as determined by the mentioned differences between CGS and TGS, implementation of rest rotational grazing, and reduction in the stocking rate) on rangeland productivity and the economic result. We did not evaluate the effects of resting and stocking rate as simple factors. Hence, we could not know if the differences observed in our study between CGS and TGS were attributable to resting, stocking rate, or both. Moreover, our results are consistent with findings by Thurow and Hussein (1989) in Somalia. These authors reported that a grazing strategy consisting of a high stocking rate and continuous grazing resulted in low levels of forage productivity, whereas a grazing strategy consisting of moderate stocking rate and rotational grazing allowed improvement of forage productivity.

Lack of a negative trend in forage productivity for TGS in our study would not have been detected because of at least two reasons: 1) NDVI methodology, as we used it, could be imprecise for estimating grass forage production, because vegetation of the Argentinean Chaco Arido region is composed of a double layer of trees and shrubs, which could mask grass forage productivity; and 2) the analysis was carried out in a degraded initial condition of the rangeland, so that a further decrease in forage productivity would not be likely.
It has been demonstrated that in arid and semiarid regions, improvements occur in ecosystems during humid years (Holmgren et al. 2001). Our results showed that the highest annual forage productivity throughout the study period occurred in $1977 / 78$, and that it was the wettest year $(604 \mathrm{~mm})$. From that year, an increase in rangeland forage productivity was observed in CGS. In this strategy, forage production over the last $6 \mathrm{yr}$ (from 1978/79 to 1983/84) almost doubled those of the two initial years (1972/73 and 1973/74). Increase in forage production is mainly associated with increase in plant vigor, increase in plant density, and/or improvements in plant species composition (Briske et al. 2003). In our study, these positive changes would have occurred in CGS related to less intense defoliation and the provision of rest, and they would have been capitalized during rainy years (1977/78). This improvement in forage productivity, triggered by a year of abundant precipitation, would have been favored by increase in soil water infiltration (due to higher plant cover and lower water runoff), enrichment in the soil seed bank of grasses, and improvement in grass reserve storages during previous years (O’Connor and Pickett 1992; Cerdá 1999; Marone et al. 2000; Holechek et al. 2001; Aguilera et al. 2003).

\section{Grazing Strategy and Economic Results}

Economic results obtained in our analysis for CGS were in agreement with the results obtained by Penna et al. (1980) in their economic study of "Balde El Tala" ranch for the period 1972/73-1977/78. This suggests that the methodology that we applied to estimate the economic results adequately represented ranch-based assessments.

Studies conducted in other Argentinean semiarid areas have shown that grazing strategies consisting of moderate stocking rates and rotational grazing produced higher economic results than grazing strategies consisting of high stocking rate and continuous grazing. Marchi et al. (1994) report that in a study conducted in a semiarid rangeland of San Luis Province (Argentina), a rotational grazing strategy coupled with the appropriate herd management showed positive economic results. Moreover, Genovés et al. (2003) reported that, in a study conducted in the same province, a grazing strategy similar to CGS showed better economic results than a grazing strategy similar to TGS, which is in agreement with our findings.

Stocking rate seems to be one of the most important factors associated with long-term economic results of cow-calf operation enterprises (Holechek et al. 1999). Kipple and Bement (1961), in the Midwest of the North American plains, observed higher economic results under moderate stocking rate than under high or low stocking rates. Campbell et al. (2000), in a semiarid region of southern Zimbabwe, found that moderate stocking rates produced higher economic results than did high stocking rates. However, Behnke et al. (1993) and Scoones (1994), in African savannas, found that grazing management utilizing high stocking rates annually adjusted to forage productivity variation showed the highest economic benefits. Carande et al. (1995) suggested that high stocking rates can give better economic results than moderate or low stocking rates only in environments with a low risk of drought occurrences. Therefore, because droughts are frequent in arid and semiarid regions (Noy-Meir 1973), high stocking rates would not be recommended. 
In our study, CGS showed better economic results than TGS. Moreover, regardless of cattle prices (normal or 20\% reduced), only CGS was able to cover the annual minimum net income required for the needs of a family. Additionally, we estimated that a minimum ranch size of 5000 ha and a herd with 350 cows are required to economically sustain a family group in a normal situation of cattle prices under CGS application. In a similar ecosystem, Genovés et al. (2003) using the same premises estimated that 6581 ha was the minimum required cattle ranch size. Discrepancies between these results may be explained because our study took into account temporal changes of rangeland productivity and simulated modifications in herd size, and furthermore incorporated the commercial method to evaluate the forage deficit or surplus. All of these variables were not considered in the Genovés et al. (2003) study. Even though there were significant effects of cattle price reduction and grazing strategy on the variation in net income, we found annual precipitation to be the most important factor associated with variation in net income. This agrees with the observations of Noy-Meir (1973) for arid and semiarid regions.

\section{MANAGEMENT IMPLICATIONS}

The findings of our study have important implications for cattle production on arid-semiarid rangelands, not only for our study region, but also for other regions of the world with similar environmental conditions. Our results indicate that applying moderate stocking rates and a rest rotation grazing strategy (CGS) improves livestock productivity and economic results of a ranch in the mid- and long terms, with respect to a high stocking rate and continuous grazing strategy (TGS). Livestock productivity and economic advantages of CGS with respect to TGS are principally associated with a rangeland forage productivity uptrend, which occurs only in the first grazing strategy. Our findings indicate that CGS would be recommended for forage capacity recuperation of overgrazing degraded rangelands. For changing from TGS to CGS, ranchers need to reduce the stocking rate to achieve a $50 \%$ forage utilization factor, and to apply a simple plan of rotational resting during the growing season. Initial reduction in herd size, to achieve CGS, could be made by keeping in the ranch animals with the highest productive potential. Change from TGS to CGS generally does not need any additional improvement in ranches of the Chaco Arido region because they often have some minimal fencing to implement rest rotational grazing. Even if there is a need to make some fencing or additional improvements to apply CGS, this can be paid by animal sales from herd size initial reduction. Considering economic, productive, and ecological advantages of the CGS over the TGS, we suggest that regional public policies should be designed to encourage a sustainable livestock production, favoring that ranchers apply CGS. These policies should consider technical support for CGS implementation, and subsidies or differential prices or taxes for ranchers applying CGS.

\section{ACKNOWLEDGMENTS}

The authors want to thank Enrique Luis Orionte for providing data from "Balde El Tala" ranch for the period 1972/73-1983/84, Jorge Vera for information on cattle prices, Juan Carlos Guevara for providing critical review of the manuscript, David Lee Anderson for providing English version revisions, and the associate editor and the four anonymous reviewers for useful comments on improving this paper.

\section{LITERATURE CITED}

Aguilera, M. O., D. F. Steinaker, and M. R. Demaría. 2003. Runoff and soil loss in undisturbed and roller-seeded shrublands of semiarid Argentina. Journal of Range Management 56:227-233.

Anderson, D. L. 1983. Compatibilidad entre pastoreo y mejoramiento de los pastizales naturales. Revista Argentina de Producción Animal 10:3-22. (In Spanish).

Anderson, D. L., J. A. Del Aguila, A. Marchi, J. C. Vera, E. L. Orionte, and A. E. Bernardón. 1980. Manejo del pastizal natural y producción ganadera. Parte 1. Buenos Aires, Argentina: Editorial Instituto de Nacional de Tecnología Agropecuaria. 60 p. (In Spanish).

Anderson, D. L., E. L. Orionte, J. C. Vera, and P. Namur. 1977. Utilización invernal de gramíneas estivales en un establecimiento ganadero de los Llanos de La Rioja. Revista de Investigaciones de Interés Agropecuario 35:321-329. (In Spanish).

Behnke, R. H., I. Scoones, and C. Kerven. 1993. Range ecology at disequilibrium: new models of natural variability and pastoral adaptation in African savannas. London, United Kingdom: Overseas Development Institute. 260 p.

BiurRun, F. N. 1988. La región de los Llanos: el deterioro del ambiente en la Argentina. Buenos Aires, Argentina: Fundación para la Educación, la Ciencia y la Cultura. 200 p. (In Spanish).

Blanco, L. J., M. O. Aguilera, J. M. Paruelo, and F. N. Biurrun. 2008. Grazing effect on NDVI across an aridity gradient in Argentina. Journal of Arid Environments 72:764-776.

Blanco, L. J., C. A. Ferrando, F. N. Biurrun, E. L. Orionte, P. Namur, D. J. Recalde, AND G. D. Berone. 2005. Forage production and vegetation attributes on rollerchopping and buffelgrass seeding in Argentina. Rangeland Ecology and Management 58:219-224.

Blanco, L. J., C. A. Ferrando, E. L. Orionte, D. J. Recalde, F. N. Biurrun, and G. Berone. 2004. Composición botánica y producción forrajera en 4 sitios de los Llanos de La Rioja. Revista Argentina de Producción Animal 24(1):111-113. (In Spanish).

Briske, D. D., J. D. Derner, J. R. Brown, S. D. Fuhlendorf, W. R. Teague, K. M. Havstad, R. L. Guillen, A. J. Ash, and W. D. Willms. 2008. Rotational grazing on rangelands: reconciliation of perception and experimental evidence. Rangeland Ecology and Management 61:3-17.

Briske, D. D., S. D. Fuhlendorf, and F. E. Smeins. 2003. Vegetation dynamics on rangelands: a critique of the current paradigms. Journal of Applied Ecology 40:601-614.

Cabido, M., C. Gonzalez, A. Acosta, and S. Díaz. 1993. Vegetation changes along a precipitation gradient in central Argentina. Vegetatio 109:5-14.

Campbell, B. M., D. Doré, B. Luckert, B. Mukamuri, and J. Gambiza. 2000. Special section: land use options in a dry tropical woodland ecosystem in Zimbabwe. Economic comparisons of livestock production in communal grazing lands in Zimbabwe. Ecological Economics 33:413-438.

Carande, V. G., E. T. Bartlett, and P. H. Gutierrez. 1995. Optimization of rangeland management strategies under rainfall and price risks. Journal of Range Management 48:66-72.

Cerdá, A. 1999. Parent material and vegetation after soil erosion in eastern Spain. Soil Science Society of American Journal 63:362-369.

Clements, F. E. 1916. Plant succession: an analysis of the development of vegetation. Washington, DC, USA: Carnegie Institute of Washington, Publication no. 242. $512 \mathrm{p}$.

DaubenmiRe, R. 1959. A canopy-coverage method of vegetation analysis. Northwest Science 33:43-65.

Del Aguila, J. A., A. E. Bernardón, and D. L. Anderson. 1969. Contribución al estudio de los pastizales naturales de los Llanos de La Rioja. Determinación de la 
carga animal. Revista de Investigaciones de Interés Agropecuario 1:81-87. (In Spanish).

Diez, H. A., H. F. Calella, J. C. Perez, G. Pignata, G. Bronstein, H. Heredia, V. Bruno, R. Santa Cruz, R. Corso, M. Sánchez Cantero, S. Corvalan, C. Ferrari, and C. Piedrabuena. 1991. Acuerdo federal para el desarrollo rural del Chaco Árido. La Rioja, Argentina: Consejo Federal de Inversiones, Documento Proyecto. 108 p. (In Spanish).

Diez, H. A., C. A. Piedrabuena, F. Benedetti, J. Penna, E. Ballec, and H. F. Callela. 1987. Desarrollo rural integral del área de Los Llanos, Provincia de La Rioja. La Rioja, Argentina: Consejo Federal de Inversiones, Documento Proyecto. 148 p. (In Spanish).

Dyksterhuis, E. J. 1949. Condition and management of range land based on quantitative ecology. Journal of Range Management 2:104-115.

Ferrando, C. A., L. Blanco, E. Orionte, F. Biurrun, D. Recalde, and P. Namur. 2001. Utilización de especies nativas por el ganado bovino en un ecosistema de Los Llanos de La Rioja. In: Resúmenes del Primer Congreso Nacional sobre Manejo de Pastizales Naturales. Santa Fe, Argentina: San Cristóbal. p. 78-79. (In Spanish).

Ferrando, C. A., and P. Namur. 1984. Resultados parciales obtenidos con la raza Criolla Argentina en el Campo Las Vizcacheras. Revista Argentina de Producción Animal 4:85-92. (In Spanish).

Genovés, J. M., J. Belgrano Rawson, E. R. Bonatti, and E. Güerri. 2003. Condicionantes económicos en la adopción de tecnología. La Estación Experimental Agropecuaria San Luis, 40 años a favor del desarrollo sustentable. Buenos Aires, Argentina: Editorial Instituto de Nacional de Tecnología Agropecuaria. 228 p. (In Spanish).

Gomez, J. C., H. F. Calella, R. R. Corzo, and A. A. Reynoso. 1993. Mapa de las subregiones de vegetación y suelo del Chaco Árido de La Rioja. Proyecto de Desarrollo Rural Integral de Los Llanos. La Rioja, Argentina: Consejo Federal de Inversiones. 162 p. (In Spanish).

Holben, B. N. 1986. Characteristic of maximum-value composite images from temporal AVHRR data. International Journal of Remote Sensing 7:1417-1434.

HoleCHEK, J. L. 1994. Financial returns from different grazing management systems in New Mexico. Rangelands 16:237-240.

Holechek, J. L., T. J. Berry, and M. Vavra. 1987. Grazing system influences on cattle performance on mountain range. Journal of Range Management 40:55-59.

Holechek, J. L., D. Galt, and J. Navarro. 2001. What's the trend? Rangelands 23:10-13.

Holechek, J. L., H. Gomez, F. Molinar, and D. Galt. 1999. Grazing studies: what we've learned? Rangelands 21:12-16.

Holm, A. M., S. W. Cridland, and M. L. Roderick. 2003. The use of time-integrated NOAA NDVI data and rainfall to assess landscape degradation in the arid shrubland of Western Australia. Remote Sensing of Environment 85:145-158.

Holmgren, M., M. Scheffer, E. Ezcurra, J. R. Gutiérrez, and G. M. J. Mohren. 2001. El Niño effects on the dynamics of terrestrial ecosystems. Trends in Ecology and Evolution 16:89-94.

Kipple, G. E., and R. E. Bement. 1961. Light grazing is economically feasible as a range-improvement practice. Journal of Range Management 14:57-62.

Marchi, A., C. Frasinelli, and B. Molinero. 1994. Propuesta tecnológica, Establecimiento "Lomas Blancas." San Luis, Argentina: INTA San Luis, Publicación Interna. 10 p. (In Spanish).
Marone, L., M. E. Horno, and R. González del Solar. 2000. Post-dispersal fate of seeds in the Monte desert of Argentina: patterns of germination in successive wet and dry years. Journal of Ecology 88:940-949.

Milchunas, D. G., and W. K. Lauenroth. 1993. Quantitative effects of grazing on vegetation and soils over a global range of environments. Ecological Monographs 63:327-366.

Morello, J. H., J. Protomastro, L. A. Sancholuz, and C. Blanco. 1985. Estudio macroecológico de Los Llanos de La Rioja. Buenos Aires, Argentina: Serie del cincuentenario de la Administración de Parques Nacionales. 53 p. (In Spanish).

Müller, B., K. Frank, and C. Wissel. 2007. Relevance of rest periods in nonequilibrium rangeland systems-a modeling analysis. Agricultural Systems 92:295-317.

Noy-MeIR, I. 1973. Desert ecosystems: environment and producers. Annual Review of Ecology and Systematics 4:25-51.

O'Connor, T. G., And G. A. Pickett. 1992. The influence of grazing on seed production and seed banks of some African savannas grasslands. Journal of Applied Ecology 29:247-260.

Oesterheld, M. O., C. M. Di Bella, and H. Kerdiles. 1998. Relation between NOAAAVHRR data and stocking rate of rangelands. Ecological Applications 8:207-212.

Orionte, E. L., P. Namur, C. Ferrando, E. Aguirre, L. Blanco, and D. Cabral. 2001. Establecimiento Balde El Tala 1971-2001: treinta años de arte y ciencia en el manejo del pastizal natural del árido riojano. In: Resúmenes del Primer Congreso Nacional sobre Manejo de Pastizales Naturales. San Cristóbal, Santa Fe, Argentina: Editorial Instituto de Nacional de Tecnología Agropecuaria. p. 28-31. (In Spanish).

Penna, J. L., R. Palazuelos, G. Escurra, and G. E. Merchante. 1980. Manejo del pastizal natural y producción ganadera. Parte 2. Buenos Aires, Argentina: Editorial Instituto de Nacional de Tecnología Agropecuaria. 30 p. (In Spanish).

Prohasca, F. J. 1959. El polo de calor de América del Sur. Revista de Investigaciones de Interés Agropecuario 141:27-30. (In Spanish).

Ragonese, A. E., and J. C. Castiglioni. 1970. La vegetación del Parque Chaqueño. Sociedad Argentina de Botánica 11:133-160. (In Spanish).

Robbins, K. R., A. M. Saxton, and L. L. Southern. 2006. Estimation of nutrient requirements using broken-line regression analysis. Journal of Animal Science 84:155-165.

SAS INSTITUTE. 1996. SAS/STAT software: changes and enhancements through release 6.11. Cary, NC, USA: SAS Institute. $1094 \mathrm{p}$.

ScOoNES, I. 1994. Living with uncertainty: new directions in pastoral development in Africa. London, United Kingdom: Intermediate Technology. 208 p.

Sellers, P. J., J. A. Berry, G. J. Collatz, C. B. Field, and F. G. Hall. 1992. Canopy reflectance, photosynthesis and transpiration. III. A reanalysis using improved leaf models and a new canopy integration scheme. Remote Sensing and Environment 12:187-216.

Thurow, T. L., And A. J. Hussein. 1989. Observation on vegetation responses to improved grazing systems in Somalia. Journal of Range Management 42:16-19.

Welden, C. W., and W. L. Slauson. 1986. The intensity of competition versus its importance: an overlooked distinction and some implications. Quarterly Review of Biology 61:23-42.

Westoby, M. B., B. Walker, And I. Noy-Meir. 1989. Opportunistic management for rangeland not at equilibrium. Journal of Range Management 42:266-274. 